\title{
Religious Values and Young People: Analysis of the Perception of Students from Secular and Religious Schools (Salesian Pedagogical Model)
}

\author{
Andrea Cívico Ariza ${ }^{1}$, Ernesto Colomo Magaña ${ }^{2, *(1)}$ and Erika González García ${ }^{3}$ (D) \\ 1 Department of Education, International University of Valencia, 46002 Valencia, Spain; \\ andrea.civico@campusviu.es \\ 2 Department of Theory and History of Education, University of Málaga, 29010 Málaga, Spain \\ 3 Department of Pedagogy, University of Granada, 18011 Granada, Spain; erikag@ugr.es \\ * Correspondence: ecolomo@uma.es
}

Received: 21 June 2020; Accepted: 11 August 2020; Published: 13 August 2020

\begin{abstract}
In a secularised and postmodernist social context, young people are increasingly distanced from religious beliefs. Nevertheless, in schools with a religious character, the main contents of the faith continue to be transmitted through the ideology and the pedagogical model. The objective of this study is to analyse the influence of the type of school on the perception of religious values. The "Adaptive Values Test" instrument was used on a sample of 456 students from secular and religious schools (Salesian) in the province of Seville during the 2018-2019 academic year. The consideration of religious values in Salesian students is also specifically analysed. The results obtained show that young people studying in schools with religious pedagogical models have a more positive view of faith than the students from secular schools. However, the rejection of the ecclesial institution occurs in students from secular schools and, to a lesser extent, in students from religious schools, becoming a common factor of distancing from religion. Young people studying in religious Salesian schools reflect significant gender differences in the perception of religious values. In these students, the exploratory factor analysis reflects three main factors, the key aspects of faith being valued more than the ecclesiastical hierarchy.
\end{abstract}

Keywords: values; religion; adolescents; religious schools; secular schools; Salesian model

\section{Introduction}

In the current context, especially among young people, religion has lost the prominence and influence it once had at the socio-cultural level. The existing distance between youth and spiritual beliefs is the result of the progressive secularization of society and the consolidation of a postmodernist religious sentiment (Bychkov 2019; Díaz 2002; Kulska 2020; Schewel 2018). Regarding secularization, in recent times it has been possible to appreciate how there has been a progressive absence of the religious at the social level linked to the different secularist policies that have been developing (Rojano 2009), along with the fragmentation of monotheism. This fact has given rise, if we consider religious belief as a factor, to profound changes in social distribution. In González-Anleo's research (González-Anleo 2017b) we can observe how $42.4 \%$ of Spanish adolescents identify themselves as Catholic, with $10.3 \%$ considering themselves practicing and $32.1 \%$ not practicing. The remaining $57.6 \%$ of the population under study was defined as agnostic $(13.6 \%)$, atheist $(23.7 \%)$, believers of other religions (5.5\%), indifferent (14.2\%), or do not know/do not answer (0.6\%). These results underline the current religious plurality in Spain, with Catholicism remaining below 50\% and with internal differences reflected in the division between practitioners and non-practitioners. These data allow us to 
get closer to grouping young people into three large groups (these are categories that aim to represent similar or dissimilar beliefs and behaviours in matters of faith at a general level, being aware that there are nuances and that the classified subjects themselves may have different perceptions of their affiliation depending on the analysis of the religious phenomenon from their subjectivity) according to the type of relationship they have with religious beliefs (González-Blasco 2006): practicing believers, who comply with both the content of their faith and with the ecclesiastical institution; nonbelievers, an increasingly numerous group made up of atheists, agnostics, and those indifferent to the religious phenomenon; and nonpracticing believers, who identify with religion on a social level but accommodate it to their interests and needs.

As for the influence of postmodernism, in the current liquid society (Bauman 2007) personal welfare is prioritized over the social, and relativism exists with respect to the principles that have constituted western society. We have gone from living in the sacred and religious (Fullat 2006) to a state of indifference and scepticism towards the spiritual, instead of liberal autonomy (Esteban 2018), where each person makes his or her decisions by virtue of his or her desires, including towards the spiritual sphere. However, religiosity is a factor that allows group cohesion and the identity construction of people in their personal and social dimensions, oriented to the subject with respect to behaviours, decisions of a moral nature and favouring critical reflection with respect to reality (Fowler and Dell 2004; Habermas 2006; Puelles 2006). There are multiple studies that find a greater psychological well-being among believers (Aldwing et al. 2014; Benefield et al. 2014; Raban and Loredana 2015; Zarzycka et al. 2020). Despite this, as Vizcaíno (2015) argued, young people are betting on "a less institutional, more personal and individual religiosity" (p. 451). It is, therefore, a subjective construction of beliefs (Beltrán 2008), giving rise to the so-called religion à la carte (González-Anleo 2006; Lipovetsky 2016). In it, religious doctrine is subordinated to the way each subject sees and understands God, producing a greater individualism, temporality, and relativity in religious praxis, with everything being linked to the preferences or needs that young people have in each context, moment, and situation. This leads to a separation from the church as an institution that marks the dogmas, norms, and premises that must be fulfilled to live religious beliefs correctly (González-Blasco 2006; Rojano 2009). In this way, the beliefs of adolescents are de-institutionalized, caused, among other reasons, by the conservative view of the same on issues such as sentimental and sexual relationships, political positioning, or the inconsistency between what they preach and the actions they develop. Because of this, the desire for transcendence is subordinated to the desire of the subject, with the crisis of religious doctrine being one of the causes of each person tending to mould a faith to his or her own measure.

Thus, in the present context, the religious sentiment of youth is more plural and subjective, the fruit of how faith is conceived on both the social and personal levels. It is important to go deeper into this vision, since adolescents are at a key point in their process of identity (re)construction, characterized by multiple changes in the physical, psychological, cognitive, and socio-affective spheres (Organización Mundial de la Salud 2018). This is a stage in which young people are asking themselves the question of who they want to be and are making the relevant axiological choices that will enable them to understand reality and shape their identity. In this process, the influence of educational agents such as the family, the peer group, the media, or the school are essential to carry out meaningful interactions that favour their holistic and integral development.

For our study, we will place the focus on the school as a socializing agent because of its role in axiological formation. The school institutions, through their ideals, define the pedagogical models that they promote through the educational process, materializing this in attitudes, norms, or behaviours that must respect the Universal Declaration of Human Rights (Organización de las Naciones Unidas 1948) and the personal and social growth of the student. These models become the road map, both pedagogical and axiological, of the educational institutions, stipulating the criteria and ethical-moral principles that will determine the climate and the school culture of these institutions. Taking into consideration the influence that the school can have on the construction of the scale of values through 
the implementation of its educational proposal and ideology, we want to investigate how students who belong to religious and secular educational institutions see and value the sphere of religious beliefs.

\subsection{Religious School and Secular School: A Common Comparison}

As we have ventured, there are differences between the secular and religious schools in the definition of their mission, vision, and values (García et al. 2016). Starting from some common values (respect, justice, solidarity, freedom, or love), the religious school tries to promote them through the faith along with the promotion of other aspects linked to religiosity, while the secular school advocates formation in citizenship and neutrality in spiritual matters. This difference has been translated into multiple comparative studies between both types of schools.

Thus, the works of Davis and Greenstein (2009) and Mather (2018) analysed attitudes towards gender among students in both types of school institutions. Academic performance by gender was also analysed in both types of schools (Battol 2012), with women's results being superior to men's, regardless of the type of school. The research by Dávila, Casabayó and Rayburn (Dávila et al. 2018) focused on materialism and the effect that schools, together with other agents such as families or the media, can have on their development. In a later study, Casabayó, Dávila and Rayburn (Casabayó et al. 2020), claimed that students whose families are believers and go to religious centres are less materialistic than students in secular centres. For his part, Tuastad (2016) went deeper in comparing moral and individual aspects between both school models, highlighting how the individual dimension (linked to autonomy) is more developed in the secular school than in the religious one. Going deeper into the moral field, the works of Bruggeman and Hart (1996) and Guttmann (1984), showed that students in both schools lied and cheated without reflecting significant differences between them. The idea of life after death was also investigated (Bering et al. 2005), and no differences were observed in the conception of the cessation of psychobiological functions after death, or in the inclusion of people with disabilities (Lifshitz and Glaubman 2002), with students from religious centres showing better attitudes. Focusing on religiosity, Hofman's (2007) research reflected the rift between secular and religious schools when dealing with the history of the Jewish religion, prioritizing the historical component over the religious one in secular schools, the opposite being the case in religious schools. For its part, the work of Dinham and Shaw (2017), analysed the role of religious education in the United Kingdom, interviewing teachers, parents, and students of both types of school, highlighting their equal views of knowing more about religions and beliefs, thus reflecting a shared awareness of the importance of religious freedom. Finally, it is worth noting the study by Uecker (2009), who carried out a comparison between students from religious schools (Protestant and Catholic) and secular schools on the level of religiosity and belief, obtaining better results in students from religious schools than in those who attend secular schools. As we can see, the comparison between these types of school is common. In our case, we were interested in knowing the axiological hierarchy and the perception of religiosity in both schools. To carry out the research, we needed to select schools of a religious character, our choice being those constituting the Salesian pedagogical model.

\subsection{Salesian Pedaogical Model}

For our study, considering this premise, we selected the sample of students from religious schools belonging to the Salesian model. The reason for this was that Don Bosco, whose personality was influenced by authors like Plato, Aristotle, or Saint Thomas Aquinas (Rodríguez and Iglesias 2018), conceived a model that had education and religion as its pillars, two interrelated aspects that are configured to give each other meaning and allow for the development of religious, holistic formation processes. The purpose, as Baeza (2013) explained, is to educate by evangelizing, starting from Christian contents as the axes in the teaching-learning process, and to evangelize through education, with the cognitive and moral development of the students being the channel to make the religious message known. 
In this way, the Salesian educational project, considered to be the result of Divine Providence (Núñez 2013), has the following aims (Alburquerque 2013; Baeza 2013; Braido 2001; Cavaglià 2013; Giraudo 2012; Graciliano 2013; López 2015; Nanni 2013; Rodríguez and Iglesias 2018; Rojano 2013; Salazar 2013): to form good citizens and honest Christians by conceiving education as the art of forming people who embrace faith and defend the fundamental rights of all individuals; to implement a model based on the three virtues of Health, Wisdom, and Holiness, being elements that must be present in the day-to-day life of each student in a constant way; starting from reason, religion, and love, to conceive love as the motor of the educational relationship where trust and common effort, directed towards the same end, must be sustained by reason and belief in God.

All these factors are adapted to the personal characteristics and stage of development of the student, thus working in a personalized educational process. In this way, we found ourselves before a model of holistic formation with a religious character, in which an education that favours the development and evolution of its protagonists is chosen. It is, therefore, an experiential, dynamic, active, and open proposal to the new challenges and interests of young people, in which its application will involve the interpretation of the different slogans and experiences that will be generated, forcing a constant reinvention to achieve the proposed goals (Izcue 2013), thus allowing its present and future validity to continue working on Don Bosco's educational dream.

Starting from the Salesian educational context, in which Don Bosco aimed at the spiritual development of his students within the Christian religion, we also wanted to know how this model influences the beliefs of his students.

\subsection{Objectives}

The religious and secular schools choose an axiological hierarchy to achieve the integral development of their students. Among the multiple elements to consider, religious beliefs are a study factor that is of interest. For all these reasons, the objective of this work is to analyse the axiological hierarchy and the perception of religious values in both types of school. We start from the hypothesis that the axiological model of religious schools is built on the ideals of faith, which encourages a better perception of the values linked to the religious fact (Court 2016). This objective includes checking whether there are significant differences, both in the category of religious values and in the terms that make up this category, between the religious school and the secular school. In this sense, although we start from the Salesian model for the religious school, we make the comparison from the perspectives of students of secular and religious schools. It is necessary to clarify this aspect, since if the object of study were to compare the perceptions of religious values between secular and religious students, with the distinctive character of the Salesian model, it would also be necessary to incorporate a comparison with other non-Salesian religious schools, a process that we have not done.

Together with this comparison, on the other hand, we want to deepen knowledge of how the Salesian pedagogical model affects its students with regard to the consideration of religious values.

The objectives to be achieved are: to verify whether the gender variable influences the vision of the terms that make up the category of religious values in the Salesian students; and to determine the underlying structure that can be deduced from the evaluation of the set of terms that make up the religious category by means of an exploratory type factorial analysis.

\section{Materials and Methods}

\subsection{Methodological Approach}

From a methodological point of view, we present a quantitative study of a descriptive nature with a non-experimental design, as no manipulations were made on the study variables. This is an empirical study in which, by means of a standardized instrument, information was collected from the sample regarding the perception of its values with the intention of being able to quantify and treat it in a statistical way. 


\subsection{Population and Sample}

The sampling was carried out using a non-probabilistic procedure (intentional selection). The population under study was made up of 456 adolescents $(n=456)$ studying in schools in the province of Seville (Spain) during the 2018/2019 school year. Of the total, 54.39\% were students of two religious schools (Salesian model) in Seville (248) and $45.61 \%$ were students of two secular schools in Seville (208). Of the subjects that made up the sample, $52.85 \%$ were women (241) and $47.15 \%$ were men (215), belonging to the 3rd (47.59\%) and 4th (52.41\%) years of Obligatory Secondary Education, including subjects aged $14(33.55 \%), 15(47.59 \%), 16(17.76 \%)$, and $17(1.10 \%)$. Data by type of school are shown in Table 1.

Table 1. Sample distribution by school and variables (gender, school year, and age).

\begin{tabular}{ccccc}
\hline \multirow{2}{*}{ Variable } & & \multicolumn{2}{c}{ School } & \multirow{2}{*}{ Total } \\
\cline { 3 - 5 } & & Religious (Salesian) & Secular & \\
\hline \multicolumn{2}{c}{ Students } & $248(54.39)$ & $208(45.61)$ & $456(100.00)$ \\
\hline \multirow{2}{*}{ Gender } & Men (\%) & $121(48.79)$ & $94(45.19)$ & $215(47.15)$ \\
& Women (\%) & $127(51.21)$ & $114(54.81)$ & $241(52.85)$ \\
\hline \multirow{2}{*}{ School year } & 3rd (\%) & $121(48.79)$ & $96(46.15)$ & $217(47.59)$ \\
& 4th (\%) & $127(51.21)$ & $112(53.85)$ & $239(52.41)$ \\
\hline \multirow{2}{*}{ Age } & $14(\%)$ & $84(33.88)$ & $69(33.17)$ & $153(33.55)$ \\
& $15(\%)$ & $120(48.38)$ & $97(46.63)$ & $217(47.59)$ \\
& $16(\%)$ & $39(15.73)$ & $42(20.20)$ & $81(17.76)$ \\
& $17(\%)$ & $5(2.01)$ & $0(0)$ & $5(1.10)$ \\
\hline
\end{tabular}

Source: authors' own work.

\subsection{Instrument}

The information was collected by applying the latest version of the Adapted Values Test (Gervilla et al. 2018), an instrument developed by the HUM-580 Research Group "Emerging values, social education and educational policies" of the University of Granada. Based on the comprehensive axiological model of Gervilla (2000a, 2000b) and his global conception of the human being according to three key dimensions (as an animal of emotional intelligence; as a singular and free being in his decisions; with the openness or relational nature of humans), the test was finally made up of 11 categories of values (corporal, intellectual, affective, individual, moral, aesthetic, social, political participation, ecological, instrumental, and religious). Each of these categories contained a total of 25 terms about which the perception of liking or disliking could be expressed by means of a Likert-type format (very unpleasant, unpleasant, indifferent, pleasant, and very pleasant). The scores ranged from -2 to 2 points, with two ranges established depending on the rating. If the results focused on the value categories, the sum of the 25 words that made up the value would be taken into account, establishing the range of scores between -50 and 50 points. On the other hand, if the focus was on the direct scores obtained by each term, the range would coincide with that established on the Likert scale for the assessment in the test ( -2 and 2 points). With regard to the criteria of instrument quality, the parameters of content validity, guaranteed by the application of the same instrument in numerous investigations (Álvarez 2002; Cámara 2010; González-Gijón et al. 2019), and reliability were considered, obtaining a Cronbach's alpha coefficient of 0.96 , which denoted acceptable reliability.

\subsection{Procedure and Data Analysis}

Once the schools had been contacted and informed, the instrument was administered to students in the 3rd and 4th year of Obligatory Secondary Education in the religious and secular schools that made up the sample by the research team. With the information already collected, data analysis was carried out with SPSS Statistics (version 25.0, IBM Corp., Armonk, NY, USA). Depending on the 
stipulated objectives, various statistical tests were developed. We began by comparing the perceptions of values of students in religious and secular schools. Firstly, an exploratory analysis of the descriptive statistics of the total responses to the test by category, together with the analysis of significant differences for the religious values category according to the school variable, were carried out. To this end, we also checked the parametric assumptions of homocedasticity and normality, obtaining in Levene's statistic a singularity higher than $0.05(p \geq 0.05)$. However, the Kolmogorov-Smirnov test (with significance correction by Lillierfors) reported a significance level lower than $0.05(p \leq 0.05)$, not adjusting to normality (Appendix A, Table A1). Because of this, parametric tests were discarded and the non-parametric Mann-Whitney U test was applied, allowing us to compare means of independent samples (school variable). Secondly, an exploratory analysis of the 25 terms that made up the category of religious values in both types of school and the analysis of significant differences for the 25 terms according to the school variable were carried out. Again, parametric assumptions were not adjusting to normality (Appendix A, Table A2), so the Mann-Whitney U test was also used.

With regard to the specific analysis of the sample of Salesian students, an analysis of significant differences was made according to the gender variable. The parametric assumptions were not adjusting to normality (Appendix A, Table A3), obtaining 9 of the 25 terms in Levene's statistic, not compatible with the application of parametric tests $(p \leq 0.05)$ and 25 terms with a significance level lower than $0.05(p \leq 0.05)$ in the Kolmogorov-Smirnov test. Therefore, the non-parametric Mann-Whitney U test was applied, allowing us to compare means of independent samples (gender variable). Finally, a multivariate data reduction technique such as exploratory factor analysis was performed to determine the underlying structure of the assessment of the terms of the category of religious values.

\section{Results}

The presentation of the results will follow the order of the research objectives set out, thus providing detailed information as a result of the analyses carried out.

\subsection{Comparative Analysis of the Axiological Perceptions of Religious and Secular School Students}

In Table 2 we can see the hierarchy of values of the sample of students from religious schools that participated in the research, applying to this the range of evaluation by categories ( -50 to 50 points) together with some data of a descriptive nature.

Table 2. Hierarchy of values of religious school students (Salesian pedagogical model).

\begin{tabular}{lccccc}
\hline \multicolumn{1}{c}{ Hierarchy of Values } & N & $\begin{array}{c}\text { Minimum } \\
\text { Value Reached }\end{array}$ & $\begin{array}{c}\text { Maximum } \\
\text { Value Reached }\end{array}$ & Mean & Standard Deviation \\
\hline 1. Affective & 248 & -4 & 50 & 38.56 & 9.51 \\
2. Moral & 248 & -1 & 50 & 35.17 & 10.90 \\
3. Individual & 248 & -6 & 50 & 33.54 & 10.20 \\
4. Corporal & 248 & -4 & 50 & 29.04 & 8.62 \\
5. Instrumental & 248 & -1 & 50 & 28.42 & 10.70 \\
6. Ecological & 248 & -50 & 50 & 27.20 & 17.28 \\
7. Social & 248 & -30 & 50 & 27.01 & 13.49 \\
8. Religious & 248 & -50 & 50 & 23.55 & 21.96 \\
9. Aesthetic & 248 & -30 & 50 & 19.37 & 13.64 \\
10. Political Participation & 248 & -50 & 50 & 14.66 & 14.28 \\
11. Intellectual & 248 & -46 & 50 & 12.50 & 15.43 \\
\hline
\end{tabular}

Source: authors' own work.

With regard to the maximum and minimum values reached by the value categories, it is worth noting that in the study sample all categories obtained a maximum value of 50 points, so that at least one student perceived all the values in that category as very pleasant. As for the minima, in three categories of values (ecological, religious, and political participation) at least one student considered 
all the words as very unpleasant ( -50 points), the perception also being close regarding the intellectual category ( -46 points). If we focus on the averages offered by the categories of values, the affective category was the one that was best evaluated by the students of the religious centres (38.56). Next to this, we would place the category of moral values (35.17) and individual values (33.54), all three being considered very pleasant. On the opposite side, with a perception close to indifference, is the category of intellectual values (12.50) and political participation (14.66). In terms of dispersion, the category in which the least variability among student responses occurred was the corporal (8.62), followed by the affective (9.51). In turn, the religious category (21.96) and the ecological category (17.28) presented the greatest heterogeneity in the responses given by the population under study. The case of the category of intellectual values (15.43) should be highlighted, due to the fact that the value of the heterogeneity of the responses was greater than the average (12.50).

Considering the data obtained at a general level, we placed the focus on the results of the category of religious values, occupying the eighth position in the hierarchical level (23.55) out of a total of eleven categories, placing itself in the intermediate zone and considered as pleasant. It presented the greatest variability in the responses (21.96) as we already underlined, it being significant that the range of the category was the maximum (100 points), shared with the ecological category and that of political participation, which meant that at least one student valued all the terms of the category (25) as very pleasant and another as very unpleasant.

Next, in Table 3 we can see the hierarchy of values of the sample of secular school students, which we will now describe.

Table 3. Hierarchy of values of secular school students.

\begin{tabular}{lccccc}
\hline \multicolumn{1}{c}{ Hierarchy of Values } & N & $\begin{array}{c}\text { Minimum } \\
\text { Value Reached }\end{array}$ & $\begin{array}{c}\text { Maximum } \\
\text { Value Reached }\end{array}$ & Mean & $\begin{array}{c}\text { Standard } \\
\text { Deviation }\end{array}$ \\
\hline 1. Moral & 208 & 18 & 50 & 44.91 & 6.49 \\
2. Individual & 208 & 11 & 50 & 43.48 & 7.85 \\
3. Affective & 208 & 21 & 50 & 42.54 & 6.53 \\
4. Ecological & 208 & 0 & 50 & 41.69 & 11.24 \\
5. Social & 208 & 11 & 50 & 36.89 & 9.39 \\
6. Corporal & 208 & 17 & 50 & 34.98 & 7.56 \\
7. Aesthetic & 208 & 2 & 50 & 28.00 & 11.42 \\
8. Instrumental & 208 & 0 & 50 & 26.28 & 11.84 \\
9. Intellectual & 208 & -3 & 50 & 19.21 & 6.55 \\
10. Political Participation & 208 & -9 & 50 & 17.11 & 7.73 \\
11. Religious & 208 & -48 & 48 & -0.58 & 21.01 \\
\hline
\end{tabular}

Source: authors' own work.

As for the maximum values, all categories obtained a maximum value of 50 points except the religious category (48 points). No student considered all the words to be very unpleasant, with no category reaching the minimum of -50 points, although the religious category came close ( -48 points). It should be noted that, along with the religious category, only political participation ( -9 points) and intellectual participation ( -3 points) scored negatively in the minimum score. For the students of the secular school, morality was the best valued category (44.91), followed closely by individual (43.48), affective (42.54), and ecological (41.69), all above 40 points and considered very pleasant. Among the worst scored, we found the intellectual (19.21) and political participation (17.11) with the consideration of pleasant, and the religious (-0.58) perceived as indifferent and with a negative score. With respect to dispersion, the least variability was present in two of the best rated categories (moral, 6.49; affective, 6.53) and one of the worst perceived (intellectual, 6.55), being the categories in which there was less difference between the students' ratings. The greatest heterogeneity occurred in the religious category (21.01), producing the greatest dispersion among the students' responses with a value much higher than their average. 
On this occasion, as we have already mentioned, the religious category obtained the worst evaluation (last position with a consideration of indifference) and the greatest dispersion (the fact being relevant that it had the highest rank in the hierarchy with a difference of 96 points) within the axiological perceptions of the students of secular schools.

For the comparison of value hierarchies, we will rely on Figure 1.

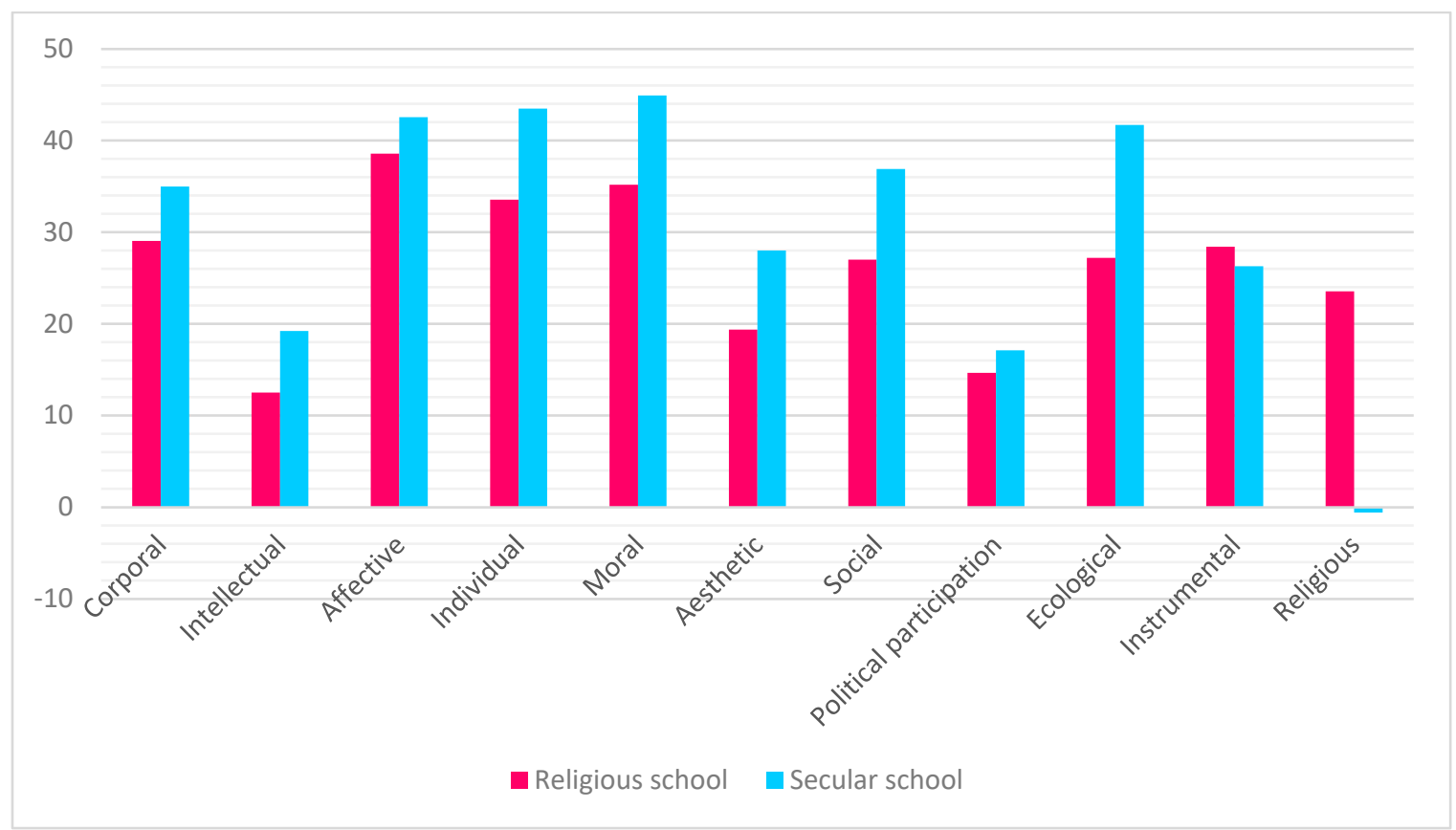

Figure 1. Comparison of the hierarchy of values between the religious schools and secular schools.

As we can see, secular school students scored higher in all value categories than religious school students, except in the instrumental and religious value categories. Some of these differences in favour of secular school students are noteworthy, such as the difference in the ecological category (14.49 points), or the individual (9.94), social (9.88), and moral (9.74), which was close to 10 points. In the case of religious school students, the difference in their favour in the instrumental category was low (2.14 points), being very high in the religious one (24.13 points). This was the greatest difference between both types of school and the object of this study, going from a negative perception of indifference in the secular school to a pleasant one in the religious school.

Once the descriptive statistics of the value hierarchy were analysed and compared in the religious school and in the secular school, we applied the Mann-Whitney U test (Table 4) to analyse if there were significant differences in the religious values category between both types of school. The results corroborated what is presented visually in Figure 1, reflecting statistically significant differences in the religious values category between schools, with religious school students (23.55) being rated much higher than secular school students $(-0.58)$.

Table 4. One-way analysis of variance of the religious values category according to the school variable.

\begin{tabular}{cccccc}
\hline Values Category & School & N & Means & Standard Deviation & Significance \\
\hline \multirow{2}{*}{ Religious } & Religious & 248 & 23.55 & 21.96 & $0.000^{*}$ \\
& Secular & 208 & -0.58 & 21.01 & \\
\hline
\end{tabular}

Source: authors' own work. ${ }^{*}=p<0.05$.

After the analysis of the hierarchy, we moved on to explore the students' perception of the terms that made up the category of religious values, using the range of assessment by terms ( -2 to 2 points). 
As in the previous objective, we will first present the perceptions of the students of the religious schools (Table 5). It should be noted that all the terms that made up the category were rated as very pleasant or very unpleasant by at least one of the students in the sample, so they all reached the maximum score ( 2 points) and minimum score ( -2 points).

Table 5. Descriptive results of the terms making up the religious values category (religious school students).

\begin{tabular}{cccccc}
\hline Hierarchy of Values & $\mathbf{N}$ & $\begin{array}{c}\text { Minimum } \\
\text { Value Reached }\end{array}$ & $\begin{array}{c}\text { Maximum } \\
\text { Value Reached }\end{array}$ & Means & $\begin{array}{c}\text { Standard } \\
\text { Deviation }\end{array}$ \\
\hline Charity & 248 & -2 & 2 & 1.29 & 0.92 \\
God & 248 & -2 & 2 & 1.26 & 1.07 \\
Baptism & 248 & -2 & 2 & 1.19 & 0.99 \\
Religious freedom & 248 & -2 & 2 & 1.19 & 1.00 \\
Procession & 248 & -2 & 2 & 1.15 & 1.06 \\
Jesus Christ & 248 & -2 & 2 & 1.14 & 1.07 \\
Believer & 248 & -2 & 2 & 1.08 & 1.08 \\
Spiritual & 248 & -2 & 2 & 1.08 & 1.05 \\
Missionary & 248 & -2 & 2 & 1.08 & 1.03 \\
Lent & 248 & -2 & 2 & 1.02 & 1.04 \\
Religious classes & 248 & -2 & 2 & 1.00 & 1.12 \\
Pray & 248 & -2 & 2 & 1.00 & 1.06 \\
Catechism & 248 & -2 & 2 & 0.96 & 1.08 \\
Church & 248 & -2 & 2 & 0.92 & 1.14 \\
Confession & 248 & -2 & 2 & 0.90 & 1.14 \\
Pope & 248 & -2 & 2 & 0.87 & 1.13 \\
Parish & 248 & -2 & 2 & 0.86 & 1.11 \\
Gospel & 248 & -2 & 2 & 0.85 & 1.09 \\
Bible & 248 & -2 & 2 & 0.83 & 1.13 \\
Priest & 248 & -2 & 2 & 0.75 & 1.11 \\
Vatican & 248 & -2 & 2 & 0.67 & 1.15 \\
Mystic & 248 & -2 & 2 & 0.65 & 1.10 \\
Mass & 248 & -2 & 2 & 0.64 & 1.17 \\
Bishop & 248 & -2 & 2 & 0.60 & 1.09 \\
Nun & 248 & -2 & 0.59 & 1.16 \\
\hline & & 248 & & \\
\hline
\end{tabular}

Source: authors' own work.

The terms charity (1.29), God (1.26), baptism (1.19), and religious freedom (1.19) got the highest scores, ranking above the consideration of pleasant but far from very pleasant. It is also significant that three of these terms obtained the lowest disposition in the responses given by the sample (charity, 0.92; baptism, 0.99; religious freedom, 1.00). If we refer to the worst perceived, although none of the terms was close to indifference ( 0 points) as they were all between 0.5 and 1 point, we found the words nun (0.59), bishop (0.60), Mass (0.64), mystic (0.65), or Vatican (0.67), with heterogeneity in the responses to the terms Mass (1.17), nun (1.16), and Vatican (1.15) being the highest of those that made up the category. It is important to highlight the fact that there were many terms with a disposition higher than the value of their average, which explained why the category of religious values obtained the greatest variability of responses in the hierarchy.

We went on to learn about the perceptions of secular school students (Table 6). Again, all the terms that made up the category were rated as very pleasant ( 2 points) or very unpleasant ( -2 points) by at least one of the students in the sample. 
Table 6. Descriptive results of the terms making up the religious values category (secular school students.

\begin{tabular}{cccccc}
\hline Hierarchy of Values & N & $\begin{array}{c}\text { Minimum } \\
\text { Value Reached }\end{array}$ & $\begin{array}{c}\text { Maximum } \\
\text { Value Reached }\end{array}$ & Means & $\begin{array}{c}\text { Standard } \\
\text { Deviation }\end{array}$ \\
\hline Charity & 208 & -2 & 2 & 1.02 & 1.02 \\
God & 208 & -2 & 2 & 0.09 & 1.22 \\
Baptism & 208 & -2 & 2 & 0.24 & 1.15 \\
Religious freedom & 208 & -2 & 2 & 1.04 & 1.11 \\
Procession & 208 & -2 & 2 & 0.05 & 1.15 \\
Jesus Christ & 208 & -2 & 2 & -0.08 & 1.18 \\
Believer & 208 & -2 & 2 & 0.05 & 1.11 \\
Spiritual & 208 & -2 & 2 & 0.47 & 1.07 \\
Missionary & 208 & -2 & 2 & 0.35 & 1.11 \\
Lent & 208 & -2 & 2 & -0.14 & 1.12 \\
Religious classes & 208 & -2 & 2 & -0.19 & 1.02 \\
Pray & 208 & -2 & 2 & -0.08 & 1.13 \\
Catechism & 208 & -2 & 2 & -0.31 & 1.04 \\
Church & 208 & -2 & 2 & -0.43 & 1.19 \\
Confession & 208 & -2 & 2 & -0.27 & 1.03 \\
Pope & 208 & -2 & 2 & -0.37 & 1.05 \\
Parish & 208 & -2 & 2 & -0.30 & 1.06 \\
Gospel & 208 & -2 & 2 & -0.22 & 1.08 \\
Bible & 208 & -2 & 2 & -0.21 & 1.10 \\
Priest & 208 & -2 & 2 & -0.37 & 1.03 \\
Vatican & 208 & -2 & 2 & -0.44 & 1.06 \\
Mystic & 208 & -2 & 2 & 0.14 & 1.07 \\
Mass & 208 & -2 & 2 & -0.32 & 1.04 \\
Bishop & 208 & -2 & 2 & -0.44 & 1.03 \\
Nun & 208 & -2 & -0.31 & 1.00 \\
\hline
\end{tabular}

Source: authors' own work.

The words religious freedom (1.04) and charity (1.02) were the best perceived, with a consideration of pleasant above 1 point. Among the worst considered, bishop and Vatican (both -0.44 points) and church (-0.43 points) stood out, close to the consideration of unpleasant. It is relevant to underline that only 9 of the 25 terms reached a positive score, in spite of being considered as indifferent, obtaining the remaining 16 a negative score. With respect to dispersion, the variability ranged from 1.00 (nun) to 1.22 (God), all the terms being located between this range, with charity being the only term whose deviation was not greater than the average (same value).

Once the descriptive statistics of the terms in the religious category were analysed for religious schools and secular schools, we applied the Mann-Whitney U test (Table 7) to make a comparison by means of inferential statistics between the scores obtained in each term according to school. The results underlined that there were significant differences in all terms except religious freedom, with the positive perception of religious school students always being superior to that of secular school students in all terms. In this way, the religious school students had a better perception of the values of the religious category analysed than their secular school counterparts. It is interesting that the only term that did not present this difference was religious freedom, having in both cases a pleasant consideration, being the fourth valued by the religious students and the first by the secular students. This close and positive perception reflected the agreement between students of religious and secular schools on the fact that people are not conditioned at the religious level, but enjoy freedom of choice. 
Table 7. One-way analysis of variance according to the school variable.

\begin{tabular}{|c|c|c|c|c|c|}
\hline Hierarchy of Values & School & $\mathbf{N}$ & Means & Standard Deviation & Significance \\
\hline \multirow{2}{*}{ Charity } & Religious & 248 & 1.29 & 0.92 & \multirow{2}{*}{$0.002 *$} \\
\hline & Secular & 208 & 1.02 & 1.02 & \\
\hline \multirow{2}{*}{ God } & Religious & 248 & 1.26 & 1.07 & \multirow{2}{*}{0.000 * } \\
\hline & Secular & 208 & 0.09 & 1.22 & \\
\hline \multirow{2}{*}{ Baptism } & Religious & 248 & 1.19 & 0.99 & \multirow{2}{*}{$0.000 *$} \\
\hline & Secular & 208 & 0.24 & 1.15 & \\
\hline \multirow{2}{*}{ Religious freedom } & Religious & 248 & 1.19 & 1.00 & \multirow{2}{*}{$0.199 *$} \\
\hline & Secular & 208 & 1.04 & 1.11 & \\
\hline \multirow{2}{*}{ Procession } & Religious & 248 & 1.15 & 1.06 & \multirow{2}{*}{$0.000 *$} \\
\hline & Secular & 208 & 0.05 & 1.15 & \\
\hline \multirow{2}{*}{ Jesus Christ } & Religious & 248 & 1.14 & 1.07 & \multirow{2}{*}{$0.000 *$} \\
\hline & Secular & 208 & -0.08 & 1.18 & \\
\hline \multirow{2}{*}{ Believer } & Religious & 248 & 1.08 & 1.08 & \multirow{2}{*}{$0.000 *$} \\
\hline & Secular & 208 & 0.05 & 1.11 & \\
\hline \multirow{2}{*}{ Spiritual } & Religious & 248 & 1.08 & 1.05 & \multirow{2}{*}{$0.000 *$} \\
\hline & Secular & 208 & 0.47 & 1.07 & \\
\hline \multirow{2}{*}{ Missionary } & Religious & 248 & 1.08 & 1.03 & \multirow{2}{*}{$0.000 *$} \\
\hline & Secular & 208 & 0.35 & 1.11 & \\
\hline \multirow{2}{*}{ Lent } & Religious & 248 & 1.02 & 1.04 & \multirow{2}{*}{$0.000 *$} \\
\hline & Secular & 208 & -0.14 & 1.12 & \\
\hline \multirow{2}{*}{$\begin{array}{l}\text { Religious } \\
\text { Classes }\end{array}$} & Religious & 248 & 1.00 & 1.12 & \\
\hline & Secular & 208 & -0.19 & 1.02 & 0.000 * \\
\hline Pray & Religious & 248 & 1.00 & 1.06 & \\
\hline Pray & Secular & 208 & -0.08 & 1.13 & $0.000^{\circ}$ \\
\hline & Religious & 248 & 0.96 & 1.08 & \\
\hline Catechism & Secular & 208 & -0.31 & 1.04 & 0.000 * \\
\hline & Religious & 248 & 0.92 & 1.14 & \\
\hline Church & Secular & 208 & -0.43 & 1.19 & $0.000^{*}$ \\
\hline & Religious & 248 & 0.90 & 1.14 & \\
\hline Confession & Secular & 208 & -0.27 & 1.03 & $0.000^{*}$ \\
\hline Pone & Religious & 248 & 0.87 & 1.13 & $0000 *$ \\
\hline Pope & Secular & 208 & -0.37 & 1.05 & $0.000^{*}$ \\
\hline & Religious & 248 & 0.86 & 1.11 & \\
\hline Parish & Secular & 208 & -0.30 & 1.06 & $0.000^{*}$ \\
\hline Cosnel & Religious & 248 & 0.85 & 1.09 & \\
\hline Gosper & Secular & 208 & -0.22 & 1.08 & 0.000 * \\
\hline Bible & Religious & 248 & 0.83 & 1.13 & \\
\hline Bible & Secular & 208 & -0.21 & 1.10 & $0.000^{*}$ \\
\hline & Religious & 248 & 0.75 & 1.11 & \\
\hline Priest & Secular & 208 & -0.37 & 1.03 & $0.000^{*}$ \\
\hline & Religious & 248 & 0.67 & 1.15 & \\
\hline Vatican & Secular & 208 & -0.44 & 1.06 & 0.000 * \\
\hline Mystic & Religious & 248 & 0.65 & 1.10 & \\
\hline Mystic & Secular & 208 & 0.14 & 1.07 & $0.000^{*}$ \\
\hline & Religious & 248 & 0.64 & 1.17 & \\
\hline Mass & Secular & 208 & -0.32 & 1.04 & $0.000^{*}$ \\
\hline Bishop & Religious & 248 & 0.60 & 1.09 & \\
\hline Bisnop & Secular & 208 & -0.44 & 1.03 & $0.000^{*}$ \\
\hline Nun & Religious & 248 & 0.59 & 1.16 & 0.000 * \\
\hline Nun & Secular & 208 & -0.31 & 1.00 & $0.000^{n}$ \\
\hline
\end{tabular}




\subsection{Specific Analysis of the Sample of Salesian Students}

After carrying out the comparative analysis between the religious and secular schools with respect to religious values, we wanted to examine the perceptions of the sample of Salesian students. In this sense, we were interested in knowing if there were significant differences in the perceptions of religious values according to the gender of the Salesian students.

We applied the Mann-Whitney $U$ test (Table 8) to make a comparison by means of inferential statistics between the scores obtained in each term according to gender. The results reflected the presence of statistically significant differences between the sexes. In all the terms that made up the religious category, women scored higher in religious values than men. In this way, it could be seen that the young women who studied in the Salesian school showed a greater perception of satisfaction with the religious question.

Table 8. One-way analysis of variance according to the variable gender of the students.

\begin{tabular}{|c|c|c|c|c|c|}
\hline Hierarchy of Values & Gender & $\mathbf{N}$ & Means & Standard Deviation & Significance \\
\hline \multirow{2}{*}{ Charity } & Man & 121 & 1.01 & 1.05 & \multirow{2}{*}{$0.000 *$} \\
\hline & Woman & 127 & 1.56 & 0.69 & \\
\hline \multirow{2}{*}{ God } & Man & 121 & 1.00 & 1.20 & \multirow{2}{*}{$0.000 *$} \\
\hline & Woman & 127 & 1.50 & 0.85 & \\
\hline \multirow{2}{*}{ Baptism } & Man & 121 & 0.96 & 1.06 & \multirow{2}{*}{$0.000 *$} \\
\hline & Woman & 127 & 1.42 & 0.87 & \\
\hline \multirow{2}{*}{ Religious freedom } & Man & 121 & 0.88 & 1.07 & \multirow{2}{*}{$0.000 *$} \\
\hline & Woman & 127 & 1.47 & 0.83 & \\
\hline \multirow{2}{*}{ Procession } & Man & 121 & 0.86 & 1.14 & \multirow{2}{*}{$0.000 *$} \\
\hline & Woman & 127 & 1.42 & 0.90 & \\
\hline \multirow{2}{*}{ Jesus Christ } & Man & 121 & 0.90 & 1.17 & \multirow{2}{*}{$0.000 *$} \\
\hline & Woman & 127 & 1.37 & 0.92 & \\
\hline \multirow{2}{*}{ Believer } & Man & 121 & 0.83 & 1.17 & \multirow{2}{*}{$0.000 *$} \\
\hline & Woman & 127 & 1.33 & 0.92 & \\
\hline \multirow{2}{*}{ Spiritual } & Man & 121 & 0.79 & 1.09 & \multirow{2}{*}{$0.000 *$} \\
\hline & Woman & 127 & 1.35 & 0.94 & \\
\hline \multirow{2}{*}{ Missionary } & Man & 121 & 0.81 & 1.08 & \multirow{2}{*}{$0.000 *$} \\
\hline & Woman & 127 & 1.33 & 0.92 & \\
\hline \multirow{2}{*}{ Lent } & Man & 121 & 0.75 & 1.08 & \multirow{2}{*}{$0.000 *$} \\
\hline & Woman & 127 & 1.28 & 0.94 & \\
\hline \multirow{2}{*}{$\begin{array}{c}\text { Religious } \\
\text { Classes }\end{array}$} & Man & 121 & 0.70 & 1.16 & \multirow{2}{*}{$0.000 *$} \\
\hline & Woman & 127 & 1.28 & 1.00 & \\
\hline \multirow{2}{*}{ Pray } & Man & 121 & 0.72 & 1.11 & \multirow{2}{*}{0.000 * } \\
\hline & Woman & 127 & 1.26 & 0.95 & \\
\hline \multirow{2}{*}{ Catechism } & Man & 121 & 0.62 & 1.12 & \multirow{2}{*}{$0.000 *$} \\
\hline & Woman & 127 & 1.29 & 0.94 & \\
\hline \multirow{2}{*}{ Church } & Man & 121 & 0.64 & 1.20 & \multirow{2}{*}{$0.000 *$} \\
\hline & Woman & 127 & 1.18 & 1.03 & \\
\hline \multirow{2}{*}{ Confession } & Man & 121 & 0.65 & 1.17 & \multirow{2}{*}{$0.000 *$} \\
\hline & Woman & 127 & 1.13 & 1.06 & \\
\hline & Man & 121 & 0.60 & 1.16 & \\
\hline Pope & Woman & 127 & 1.13 & 1.04 & $0.000 *$ \\
\hline
\end{tabular}


Table 8. Cont

\begin{tabular}{|c|c|c|c|c|c|}
\hline Hierarchy of Values & Gender & $\mathbf{N}$ & Means & Standard Deviation & Significance \\
\hline \multirow{2}{*}{ Parish } & Man & 121 & 0.64 & 1.16 & \multirow{2}{*}{$0.000 *$} \\
\hline & Woman & 127 & 1.07 & 1.03 & \\
\hline \multirow{2}{*}{ Gospel } & Man & 121 & 0.55 & 1.13 & \multirow{2}{*}{$0.000 *$} \\
\hline & Woman & 127 & 1.14 & 0.97 & \\
\hline \multirow{2}{*}{ Bible } & Man & 121 & 0.51 & 1.19 & \multirow{2}{*}{$0.000 *$} \\
\hline & Woman & 127 & 1.13 & 0.98 & \\
\hline \multirow{2}{*}{ Priest } & Man & 121 & 0.50 & 1.12 & \multirow{2}{*}{$0.000 *$} \\
\hline & Woman & 127 & 0.98 & 1.05 & \\
\hline \multirow{2}{*}{ Vatican } & Man & 121 & 0.43 & 1.22 & \multirow{2}{*}{$0.000 *$} \\
\hline & Woman & 127 & 0.89 & 1.03 & \\
\hline \multirow{2}{*}{ Mystic } & Man & 121 & 0.42 & 1.12 & \multirow{2}{*}{$0.000 *$} \\
\hline & Woman & 127 & 0.87 & 1.03 & \\
\hline \multirow{2}{*}{ Mass } & Man & 121 & 0.32 & 1.18 & \multirow{2}{*}{$0.000 *$} \\
\hline & Woman & 127 & 0.94 & 1.09 & \\
\hline \multirow{2}{*}{ Bishop } & Man & 121 & 0.37 & 1.06 & \multirow{2}{*}{$0.000 *$} \\
\hline & Woman & 127 & 0.81 & 1.09 & \\
\hline \multirow{2}{*}{ Nun } & Man & 121 & 0.36 & 1.10 & \multirow{2}{*}{$0.000 *$} \\
\hline & Woman & 127 & 0.81 & 1.17 & \\
\hline
\end{tabular}

Source: authors' own work; ${ }^{*}=p<0.05$.

To check the underlying structure that can be deduced from the assessment of the words that made up the religious category, a multivariate data reduction technique was applied, such as exploratory factor analysis. To this end, it was necessary to verify the suitability of the factorial analysis by obtaining the determinant of the correlation matrix, the Kaiser-Meyer-Olkin (KMO) sample suitability measure, the Bartlett sphericity test, the sample suitability measures of each variable (MSA), and the partial correlations (Table 9). Both the sample adequacy measure $(\mathrm{KMO}=0.962)$ and the Bartlett sphericity index, with an approximate chi-square of 6980.816 and an associated probability $=0.000$ statistically significant, confirmed the adequacy of the factor analysis calculation. The determinant of the correlation matrix should also be considered, which should be close to 0 . In this case, the value was $1.789 \times 10^{-13}$, which meant that the variables were linearly related.

Table 9. Kaiser-Meyer-Olkin (KMO) and Bartlett's test.

\begin{tabular}{ccc}
\hline \multicolumn{2}{c}{ Means of Kaiser-Meyer-Olkin Adequacy of the Sample } & $\mathbf{0 . 9 6 2}$ \\
\hline & approximate chi-squared & 6980.816 \\
Bartlett's Sphericity Test & Gl & 300 \\
& Sig. & 0.000 * \\
\hline
\end{tabular}

Source: authors' own work; ${ }^{*}=p<0.05$.

The anti-image correlation matrix provided by SPSS showed MSA values higher than 0.932 in all cases, while partial correlation values between words in the religious vocabulary category were low. The results of this relevant factorial analysis, which we will now comment on, have the necessary methodological guarantees.

\subsection{Main Results of the Calculated Factor Analysis}

Table 10 shows the self-values of the variance-covariance matrix and the percentage of variance that each one of them represents. Three components were obtained for the study sample that enabled the explanation of $75.41 \%$ of the variance of the original data, denoting a clear unipolar character. 
Table 10. Total variance explained.

\begin{tabular}{|c|c|c|c|c|c|c|c|c|c|}
\hline \multirow{2}{*}{ Comp. } & \multicolumn{3}{|c|}{ Initial Self Values } & \multicolumn{3}{|c|}{$\begin{array}{c}\text { Sums of Charges Squared } \\
\text { Extraction }\end{array}$} & \multicolumn{3}{|c|}{$\begin{array}{c}\text { Sums of Charges Squared } \\
\text { Extraction }\end{array}$} \\
\hline & Total & $\begin{array}{c}\% \\
\text { Variance }\end{array}$ & $\begin{array}{c}\% \\
\text { Accumulated }\end{array}$ & Total & $\%$ Var. & $\%$ Acc. & Total & $\%$ Var. & $\%$ Acc. \\
\hline 1 & 16.515 & 66.06 & 66.06 & 16.515 & 66.06 & 66.06 & 9.38 & 37.52 & 37.52 \\
\hline 2 & 1.328 & 5.31 & 71.37 & 1.328 & 5.31 & 71.37 & 5.76 & 23.02 & 60.54 \\
\hline 3 & 1.010 & 4.04 & 75.41 & 1.010 & 4.04 & 75.41 & 3.72 & 14.87 & 75.41 \\
\hline
\end{tabular}

Source: authors' own work; $p<0.05$.

It should be noted that since the terms saturated all three components at the same time, each term was associated with the component with the highest level of saturation, as reflected in the matrix of rotated components (Table 11).

Table 11. Matrix of rotated components *

\begin{tabular}{|c|c|c|c|}
\hline \multirow{2}{*}{ Religious Values } & \multicolumn{3}{|c|}{ Component } \\
\hline & 1 & 2 & 3 \\
\hline Charity & 0.395 & 0.203 & 0.752 \\
\hline God & 0.789 & 0.226 & 0.327 \\
\hline Baptism & 0.714 & 0.251 & 0.325 \\
\hline Religious freedom & 0.299 & 0.240 & 0.721 \\
\hline Procession & 0.532 & 0.186 & 0.500 \\
\hline Jesus Christ & 0.761 & 0.258 & 0.412 \\
\hline Believer & 0.799 & 0.297 & 0.318 \\
\hline Spiritual & 0.710 & 0.364 & 0.409 \\
\hline Missionary & 0.125 & 0.587 & 0.626 \\
\hline Lent & 0.760 & 0.372 & 0.347 \\
\hline Religious classes & 0.473 & 0.299 & 0.518 \\
\hline Pray & 0.757 & 0.315 & 0.334 \\
\hline Catechism & 0.744 & 0.349 & 0.349 \\
\hline Church & 0.737 & 0.451 & 0.183 \\
\hline Confession & 0.700 & 0.328 & 0.248 \\
\hline Pope & 0.511 & 0.639 & 0.305 \\
\hline Parish & 0.589 & 0.557 & 0.294 \\
\hline Gospel & 0.758 & 0.511 & 0.171 \\
\hline Bible & 0.759 & 0.423 & 0.167 \\
\hline Priest & 0.542 & 0.669 & 0.248 \\
\hline Vatican & 0.542 & 0.613 & 0.206 \\
\hline Mystic & 0.277 & 0.653 & 0.392 \\
\hline Mass & 0.621 & 0.561 & 0.223 \\
\hline Bishop & 0.400 & 0.823 & 0.202 \\
\hline Nun & 0.236 & 0.847 & 0.201 \\
\hline
\end{tabular}

Source: authors' own work. Extraction method: principal component analysis. Rotation method: normalization Varimax with Kaiser. * The rotation has converged in 8 iterations.

Self-value 1 , with a score of 16.515 , explained $66.06 \%$ of the variance, being made up of the terms with $r \pm 0.30$ in that component, and which did not score more in another of the components, among which we find God, baptism, procession, Jesus Christ, believer, spiritual, Lent, pray, catechism, church, confession, parish, gospel, bible and Mass. The self-value 2 (1328) explained 5.31\% of the variance, including the words Pope, priest, Vatican, mystic, bishop and nun. Self-value 3 (1010) explained $4.04 \%$ of the variance, where the rest of the terms of the religious category were collected (charity, religious freedom, missionary, and religion classes). The distribution of the terms in the components is reflected in Figure 2. 


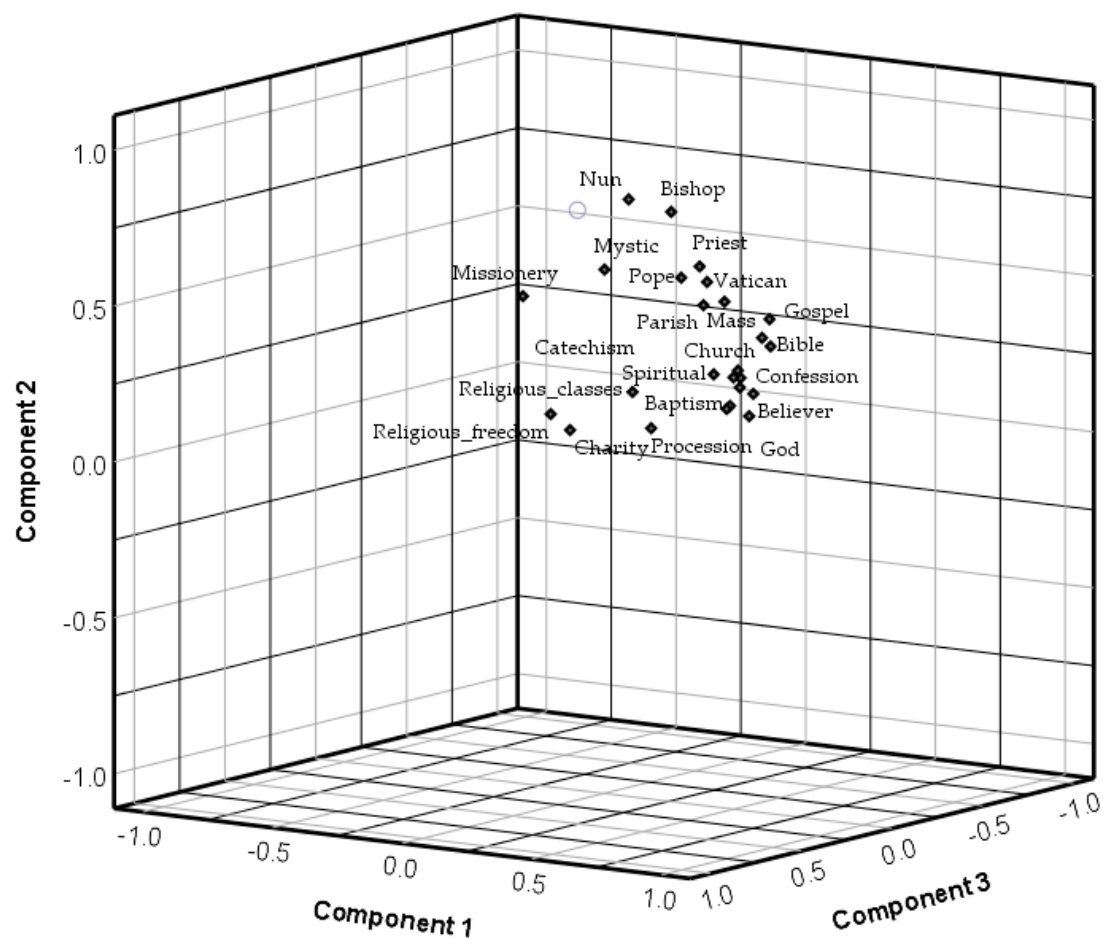

Figure 2. Figure of rotated components in Space.

\section{Discussion and Conclusions}

Starting from the current context of liquid spirituality in Spain (Vizcaíno 2015), this study aimed to compare the influence that school can have on the perception of religious values, making a comparison between students from secular and religious schools. Along with this, we wanted to know, in greater depth, what the Salesian students' views were of religious values according to gender and the importance they gave to the different elements that make up religion.

If we look at the axiological hierarchy of the sample under study, regardless of the category of religious values, the first places of the affective, moral, and individual values coincide with different studies (Álvarez 2006; Álvarez and Rodríguez 2008). On the other hand, placed in the last positions are the axiological categories of political participation, as endorsed in the studies of González-Anleo (2017a) and López-Ruiz (2017), and intellectual values, as in the investigation of Cívico et al. (2019). Thus, with respect to the hierarchy of values without considering the religious factor, the results reflected similarities in the perceptions of the students of both types of schools, coinciding with the results of the work of García, Grimaldo and Manzanares (García et al. 2016). After that, we focused exclusively on religious values, the main object of our research. For secular school students, the category of religious values occupied the last position. This coincides with the studies by Gervilla (2002) or Elzo (2006), in which the religious sphere was ranked as the least valued; with the Report on Youth in Spain 2016 (Benedicto 2017), where Catholicism had become a mere cultural reference for young people, it was reflected in the positions of detachment, indifference, or scepticism towards religious beliefs on the part of a sample of 5002 young Spaniards, and the data of López-Ruiz (2017), where only 3.8\% of Spanish young people (the total sample of the study amounted to 1250 young people between 15 and 24 years old, distributed throughout the country) thought that the church talked about things that are important for life, compared to $61.6 \%$ for family, $48.2 \%$ for friends, or $33.1 \%$ for school. On the other hand, the students of religious schools placed the religious category in eighth place with a rating of pleasant, thus distancing this category from the last position in the axiological hierarchy for these schoolchildren. In the midst of a secularized social reality in which religious beliefs are adapted to the personal needs of each subject (Lipovetsky 2016), the implementation of a religious pedagogical model in schools, as is the case with the Salesian, influences a positive perception of the faith by 
students, coinciding with the results of Jokić (2015) or Rymarz and Cleary (2018). Despite the better appreciation of religious students, there is, in general, a distancing of young Spaniards from religious beliefs. This was reflected in the last position they occupy in the hierarchy of secular students and the eighth position (the total of categories is eleven) for religious students. Based on the comparison, the students of religious schools have a better perception of religious values compared to those of secular schools, with significant differences. This does not coincide with the results of Gobernado (2003), who stated that there is little difference in the responses of students from religious and non-religious centres (public, subsidised, or private) with respect to their religious perception. On the contrary, it does coincide with the work of Hofmann (2007), where it is evident that the change in the perception of values among religious and secular school students is linked to the level of religiosity present in them; and that of Barret et al. (2007), who highlighted the positive influence that religious schools have on the religious beliefs, attitudes, and behaviour of their students.

With respect to the analysis of the different terms that made up the category of religious values, the evaluation of students in religious schools was superior to that of students in secular schools in all the terms analysed. Statistically significant differences were produced in all terms except religious freedom, because it was considered very positively by students in both types of schools. The greatest differences were found in the aspects related to faith, something that also occurred in the studies of Uecker $(2008$, 2009). Regarding those aspects that were best considered by both types of schools, we found aspects such as charity and religious freedom. Although it is true that charity has an important religious connotation in one of its meanings as a theological virtue (Real Academia Española 2019), the action of giving and helping the most needy is present in other axiological categories such as the social, so its good evaluation is linked to its semantic plurality and not only to the theological conception of the term. On the other hand, religious freedom was valued by students, starting from the premise that, independent of the belief or lack of belief in a certain faith, religious freedom must be respected because it is a fundamental right (Ibáñez 2002, 2006; Organización de las Naciones Unidas 1948). For religious students, the term God also stood out among the most valued. In this case, we speak of a strong belief among young Spanish Catholics (González-Anleo 2017b), characterized by an image of a God who is close to and attentive to their personal reality (González-Anleo 2006), His figure being more important for women than for men. If we put the focus on the worst valued in both types of schools, we found different ecclesiastical figures, such as a bishop or a nun, with Vatican and church for secular students and the sacrament of the Mass for religious students. The low valuations around the ministry of the church coincide with various studies (Díaz et al. 2006; Romero 2010) where the religious vision of adolescents, from both schools, is framed in the personal and subjective sphere, disassociating itself from the church as an institution and the figures that represent it. Another aspect to be highlighted, taking into account the Salesian character of the students from religious schools, is the antepenultimate position occupied by the Mass. We cannot forget that it is a fundamental sacrament in the Salesian conception of the educational process, since Eucharistic devotion is considered as a principle for people's salvation (Alburquerque 2013). Nevertheless, this lower evaluation coincides with the data of the study by González-Anleo (2017b), which reflected that $78.1 \%$ of Spanish youth never or practically never attend church.

Focusing on the specific analysis of the sample of Salesian students, this study sought to understand how the Salesian pedagogical model affected the consideration of religious values. Starting from it, if we look at the analysis of the axiological perception of the religious sphere according to the gender variable, the women reflected a more positive assessment of the religious fact than men, coinciding with the studies by Ter Avest et al. (2010), Holm et al. (2014), and Muñoz-García and Villena-Martínez (2018). However, the difference between men and women is not always reflected in the research (Benedicto 2017; Funes 2008), since elements such as the relevance given to religion (10.5\% very important for women compared to $8.5 \%$ for men) or the percentage of young people who define themselves as atheists or nonpracticing Catholics (for atheists, $18.6 \%$ men versus $15.8 \%$ of women; for nonpracticing Catholics, $36.2 \%$ of men versus $42.2 \%$ of women) are similarly distributed between both sexes. 
Another important aspect is to see how the terms we analysed were grouped around two main components: key aspects of the faith and the ministry of the church. The first factor, encompassing the key principles of the Christian religion, includes God and Jesus Christ, many of the sacraments and other aspects linked to faith. This component, with positive evaluations of the different terms that made up the sample, reflects that religious belief was perceived as important by the Salesian students, coinciding with the work of Cnaan et al. (2004). With regard to the terms that made up the ministry factor of the church, they were the least well-perceived by these students. This is due to a change in the way of conceiving religious practice, where the intercession of the church is dispensed with in order to believe in God, and where the church can accept or reject norms and guidelines depending on how they fit their interests and needs. This vision is related to different studies (González-Anleo 2006; González-Blasco 2006; Valls 2010), whose data affirmed that the church is the Spanish institution that generates the most distrust among young people and where the least important things about life are said, thus reducing religious practice and the link with the institutional. As Professor Gervilla (2006) states, "What is in crisis is institutional religion due to its isolation or irrelevance" (Gervilla 2006, p. 461).

To conclude, among the limitations we underline the sample of participants, both from religious and secular schools, to get a broader view of the perception of religious values in both types of school. Along with this, if we want to analyse the distinctive character of the Salesian approach, it would be necessary to include students from different religious schools, with orders such as Jesuits, Piarists, or Vincentians. Another limitation is the non-inclusion of other variables and instruments for collecting information that complement and add value to the information reported by the test, such as information on families' beliefs or reasons for choosing one type of facility or another.

In this sense, for future research we contemplate the expansion of both the number of students in religious and secular schools and the inclusion of other educational institutions of a religious nature (Jesuits, Piarists, Vincentians, etc.). In addition, we also intend to incorporate interviews that will allow us to reflect on the results obtained in the evaluations, as well as to investigate their opinions regarding how religion influences culture and the school climate, or the role of the subject of religion and the competencies and contents linked to it. Along with this, it is key to incorporate the family variable for the analysis of religious values, as it can provide interesting information on the religious issue, as reflected in the study by Sander and Cohen-Zada (2012), where families with religious beliefs are the ones who mostly choose this type of school for their children, thus influencing a more positive perception of this axiological dimension (Casabayó et al. 2020). For all these reasons, these variables will be present in future research.

Author Contributions: Conceptualization, A.C.A. and E.G.G.; methodology, A.C.A.; software, E.C.M.; formal analysis, E.C.M.; investigation, A.C.A. and E.G.G.; resources, E.G.G.; data curation, E.C.M.; writing-original draft preparation, A.C.A.; writing-review and editing, E.C.M. and E.G.G.; supervision, E.C.M. All authors have read and agreed to the published version of the manuscript.

Funding: This research received no external funding.

Conflicts of Interest: The authors declare no conflict of interest.

\section{Appendix A}

Table A1. Results of the parametric assumptions for the school variable (religious values category).

\begin{tabular}{|c|c|c|c|c|c|}
\hline \multirow{2}{*}{ Hierarchy of Values } & \multirow{2}{*}{ School } & \multicolumn{2}{|c|}{ Levene } & \multicolumn{2}{|c|}{ Kolmogorov-Smirnov } \\
\hline & & Statistical & Sig. & Statistical & Sig. \\
\hline Religious & $\begin{array}{l}\text { Religious } \\
\text { Secular }\end{array}$ & 2.243 & 0.135 & $\begin{array}{l}0.114 \\
0.203\end{array}$ & $\begin{array}{l}0.000 \\
0.000\end{array}$ \\
\hline
\end{tabular}

Source: authors' own work; $p<0.05$. 
Table A2. Results of the parametric assumptions for the school variable (religious values).

\begin{tabular}{|c|c|c|c|c|c|}
\hline \multirow{2}{*}{ Hierarchy of Values } & \multirow{2}{*}{ School } & \multicolumn{2}{|c|}{ Levene } & \multicolumn{2}{|c|}{ Kolmogorov-Smirnov } \\
\hline & & Statistical & Sig. & Statistical & Sig. \\
\hline \multirow{2}{*}{ Baptism } & Religious & \multirow{2}{*}{1.708} & \multirow[b]{2}{*}{0.192} & 0.300 & 0.000 \\
\hline & Secular & & & 0.225 & 0.000 \\
\hline \multirow{2}{*}{ Bible } & Religious & \multirow{2}{*}{2.007} & \multirow{2}{*}{0.157} & 0.197 & 0.000 \\
\hline & Secular & & & 0.282 & 0.000 \\
\hline \multirow{2}{*}{ Charity } & Religious & \multirow{2}{*}{0.588} & \multirow{2}{*}{0.443} & 0.320 & 0.000 \\
\hline & Secular & & & 0.265 & 0.000 \\
\hline \multirow{2}{*}{ Catechism } & Religious & \multirow{2}{*}{0.964} & \multirow{2}{*}{0.327} & 0.246 & 0.000 \\
\hline & Secular & & & 0.309 & 0.000 \\
\hline \multirow{2}{*}{ Religious classes } & Religious & \multirow{2}{*}{3.824} & \multirow{2}{*}{0.051} & 0.250 & 0.000 \\
\hline & Secular & & & 0.299 & 0.000 \\
\hline \multirow{2}{*}{ Confession } & Religious & & & 0.236 & 0.000 \\
\hline & Secular & 6.236 & 0.013 & 0.312 & 0.000 \\
\hline & Religious & & & 0.291 & 0.000 \\
\hline Believer & Secular & 3.270 & 0.071 & 0.274 & 0.000 \\
\hline Jent & Religious & 0226 & 0634 & 0.257 & 0.000 \\
\hline Lent & Secular & 0.226 & 0.634 & 0.296 & 0.000 \\
\hline & Religious & & 0,538 & 0.341 & 0.000 \\
\hline God & Secular & 0.379 & 0.538 & 0.246 & 0.000 \\
\hline Spiritual & Religious & & & 0.270 & 0.000 \\
\hline Spiritual & Secular & 0.075 & 0.784 & 0.214 & 0.000 \\
\hline & Religious & & & 0.220 & 0.000 \\
\hline Gospel & Secular & 2.734 & 0.099 & 0.303 & 0.000 \\
\hline & Religious & & & 0.244 & 0.000 \\
\hline Church & Secular & 1.056 & 0.305 & 0.233 & 0.000 \\
\hline Jesus Christ & Religious & 0136 & 0712 & 0.300 & 0.000 \\
\hline & Secular & 0.100 & 0.712 & 0.271 & 0.000 \\
\hline Religious freedom & Religious & 0669 & & 0.297 & 0.000 \\
\hline & Secular & 0.669 & 0.414 & 0.258 & 0.000 \\
\hline & Religious & & & 0.183 & 0.000 \\
\hline Mass & Secular & 8.716 & 0.003 & 0.328 & 0.000 \\
\hline & Religious & & & 0.266 & 0.000 \\
\hline Missionary & Secular & 1.051 & 0.306 & 0.215 & 0.000 \\
\hline Mystic & Religious & & & 0.212 & 0.000 \\
\hline Mystic & Secular & 6.935 & 0.009 & 0.283 & 0.000 \\
\hline Nup & Religious & 10114 & 0002 & 0.176 & 0.000 \\
\hline & Secular & 10.114 & 0.002 & 0.342 & 0.000 \\
\hline Bishop & Religious & 1614 & 0205 & 0.199 & 0.000 \\
\hline & Secular & 1.614 & 0.205 & 0.320 & 0.000 \\
\hline Pone & Religious & & & 0.256 & 0.000 \\
\hline Pope & Secular & 6.699 & 0.010 & 0.319 & 0.000 \\
\hline & Religious & & & 0.222 & 0.000 \\
\hline Parish & Secular & 2.972 & 0.085 & 0.322 & 0.000 \\
\hline Procession & Religious & 0.588 & 0.443 & 0.302 & 0.000 \\
\hline Procession & Secular & 0.588 & 0.443 & 0.253 & 0.000 \\
\hline Pray & Religious & 0002 & 0.965 & 0.228 & 0.000 \\
\hline & Secular & 0.002 & 0.965 & 0.296 & 0.000 \\
\hline Priest & Religious & 3976 & 0047 & 0.206 & 0.000 \\
\hline Priest & Secular & 3.976 & 0.047 & 0.328 & 0.000 \\
\hline Vatican & Religious & 3445 & 0064 & 0.207 & 0.000 \\
\hline vatican & Secular & 0.443 & 0.004 & 0.300 & 0.000 \\
\hline
\end{tabular}

Source: authors' own work; $p<0.05$. 
Table A3. Results of the parametric assumptions for the gender variable in Salesian students.

\begin{tabular}{|c|c|c|c|c|c|}
\hline \multirow{2}{*}{ Hierarchy of Values } & \multirow{2}{*}{ Gender } & \multicolumn{2}{|c|}{ Levene } & \multicolumn{2}{|c|}{ Kolmogorov-Smirnov } \\
\hline & & Statistical & Sig. & Statistical & Sig. \\
\hline \multirow{2}{*}{ Baptism } & Man & \multirow{2}{*}{3.480} & \multirow[b]{2}{*}{0.063} & 0.234 & 0.000 \\
\hline & Woman & & & 0.363 & 0.000 \\
\hline \multirow{2}{*}{ Bible } & Man & \multirow{2}{*}{5.879} & \multirow{2}{*}{0.016} & 0.193 & 0.000 \\
\hline & Woman & & & 0.262 & 0.000 \\
\hline \multirow{2}{*}{ Charity } & Man & \multirow{2}{*}{10.170} & \multirow{2}{*}{0.002} & 0.234 & 0.000 \\
\hline & Woman & & & 0.409 & 0.000 \\
\hline \multirow{2}{*}{ Catechism } & Man & \multirow{2}{*}{6.622} & \multirow{2}{*}{0.011} & 0.198 & 0.000 \\
\hline & Woman & & & 0.319 & 0.000 \\
\hline \multirow{2}{*}{ Religious classes } & Man & \multirow{2}{*}{3.021} & \multirow{2}{*}{0.083} & 0.196 & 0.000 \\
\hline & Woman & & & 0.330 & 0.000 \\
\hline \multirow{2}{*}{ Confession } & Man & & & 0.188 & 0.000 \\
\hline & Woman & 3.574 & 0.060 & 0.282 & 0.000 \\
\hline & Man & 8301 & 0004 & 0.231 & 0.000 \\
\hline Believer & Woman & 8.391 & 0.004 & 0.350 & 0.000 \\
\hline Jent & Man & 3390 & 0067 & 0.196 & 0.000 \\
\hline Lent & Woman & 3.390 & $0.06 \%$ & 0.320 & 0.000 \\
\hline & Man & 15028 & 0000 & 0.284 & 0.000 \\
\hline God & Woman & 15.028 & 0.000 & 0.397 & 0.000 \\
\hline Spiritual & Man & & & 0.189 & 0.000 \\
\hline Spiritual & Woman & 3.018 & 0.084 & 0.348 & 0.000 \\
\hline Gosnel & Man & 3507 & 0062 & 0.200 & 0.000 \\
\hline Gosper & Woman & 3.507 & 0.062 & 0.283 & 0.000 \\
\hline & Man & & & 0.178 & 0.000 \\
\hline Church & Woman & 4.190 & 0.042 & 0.307 & 0.000 \\
\hline Jesus Christ & Man & 6561 & 0.011 & 0.241 & 0.000 \\
\hline & Woman & 6.561 & 0.011 & 0.359 & 0.000 \\
\hline Religious freedom & Man & 8373 & 0004 & 0.216 & 0.000 \\
\hline & Woman & 8.373 & 0.004 & 0.374 & 0.000 \\
\hline & Man & & & 0.211 & 0.000 \\
\hline Mass & Woman & 0.789 & 0.375 & 0.236 & 0.000 \\
\hline Missionary & Man & 3402 & 0066 & 0.195 & 0.000 \\
\hline VIIISSIOHIdary & Woman & 3.402 & 0.066 & 0.334 & 0.000 \\
\hline Mystic & Man & 0359 & 0550 & 0.233 & 0.000 \\
\hline Mystic & Woman & 0.359 & 0.550 & 0.217 & 0.000 \\
\hline Nun & Man & 0.633 & 0427 & 0.208 & 0.000 \\
\hline Nun & Woman & 0.633 & 0.427 & 0.208 & 0.000 \\
\hline Bishop & Man & 0.597 & 0441 & 0.214 & 0.000 \\
\hline & Woman & 0.597 & 0.441 & 0.209 & 0.000 \\
\hline Pone & Man & & & 0.225 & 0.000 \\
\hline Pope & Woman & 1.738 & 0.189 & 0.317 & 0.000 \\
\hline & Man & & & 0.175 & 0.000 \\
\hline Parish & Woman & 1.567 & 0.212 & 0.280 & 0.000 \\
\hline$D_{m}$ & Man & 7.780 & 0007 & 0.221 & 0.000 \\
\hline Procession & Woman & 7.478 & 0.007 & 0.380 & 0.000 \\
\hline Pray & Man & 2487 & 0116 & 0.212 & 0.000 \\
\hline & Woman & 2.487 & 0.116 & 0.303 & 0.000 \\
\hline D. & Man & $060 ?$ & 0020 & 0.225 & 0.000 \\
\hline Priest & Woman & 0.603 & 0.438 & 0.259 & 0.000 \\
\hline Vatican & Man & 1976 & 0161 & 0.197 & 0.000 \\
\hline vatican & Woman & 1.970 & 0.101 & 0.245 & 0.000 \\
\hline
\end{tabular}

Source: authors' own work; $p<0.05$. 


\section{References}

Alburquerque, Eugenio. 2013. Espiritualidad de don Bosco. Educación y Futuro 28: 39-60.

Aldwing, Carolyn M., Crystal L. Park, Yu-Jin Jeong, and Ritwik Nath. 2014. Differing Pathways between Religiousness, Spirituality, and Health: A Self-Regulation Perspective. Psychology of Religion and Spirituality 6: 9-21. [CrossRef]

Álvarez, José. 2002. Análisis descriptivo de los valores sentimiento y emoción en la formación de profesores de la Universidad de Granada. Profesorado, Revista de Currículum y Formación del Profesorado 6: 1-13.

Álvarez, José. 2006. Los valores afectivos en la formación inicial del profesorado. Estudio inicial. Cuestiones Pedagógicas 18: 121-41.

Álvarez, José, and Clemente Rodríguez. 2008. El valor de la institución familiar en los jóvenes universitarios de la universidad de Granada. Bordón 60: 7-21.

Baeza, Jorge. 2013. Educación Superior e Inclusión Social: Una perspectiva desde las Instituciones Universitarias Salesianas. Educación y Futuro 28: 201-22.

Barret, Jennifer. B., Jennifer Pearson, Chandra Muller, and Kenneth A. Frank. 2007. Adolescent religiosity and school contexts. Social Science Quarterly 88: 1024-37. [CrossRef]

Battol, Sadia. 2012. Gender differences in the academic achievement of mainstream and religious school students. Journal of educational Sciences \& Psychology 2: 76-80.

Bauman, Zygmunt. 2007. Los Retos de la Educación en la Modernidad Líquida. Barcelona: Gedisa.

Beltrán, William. 2008. Secularización: ¿teoría o paradigma? Revista Colombiana de Sociología 32: 61-81.

Benedicto, Jorge. 2017. Informe Juventud en España 2016. Madrid: Instituto de la Juventud.

Benefield, Margaret, Louis W. Fry, and David Geigle. 2014. Spirituality and Religion in the Workplace: History, Theory, and Research. Psychology of Religion and Spirituality 6: 175-87. [CrossRef]

Bering, Jesse M., Carlos H. Blasi, and David. F. Bjorklund. 2005. The development of "afterlife" beliefs in religiously and seculary schooled children. British Journal of Developmental Psychology 23: 587-607. [CrossRef] [PubMed]

Braido, Pietro. 2001. El Sistema Preventivo. Prevenir no Reprimir. Madrid: CCS.

Bruggeman, Elizabeth Leistler, and Kathleen J. Hart. 1996. Cheating, lying, and moral reasoning by religious and secular high school students. Journal of Educational Research 89: 340-44. [CrossRef]

Bychkov, Victor. 2019. Aesthetic Experience as a Spiritual Support of Homo Post-Secularis. Religions 10: 250. [CrossRef]

Cámara, África. 2010. Valores en futuros profesores de Secundaria. Revista Electrónica Interuniversitaria de Formación del Profesorado 13: 113-21.

Casabayó, Mónica, Juan Francisco Dávila, and Steven W. Rayburn. 2020. Thou shalt not covet: Role of family religiosity in anti-consumption. International Journal of Consumer Studies 44: 445-54. [CrossRef]

Cavaglià, Piera. 2013. La relación educativa en don Bosco: Un tesoro. Educación y Futuro 28: 83-100.

Cívico, Andrea, Erika González, and Ernesto Colomo. 2019. Análisis de la percepción de valores relacionados con las TIC en adolescentes. Revista Espacios 40: 18. Available online: https://www.revistaespacios.com/ a19v40n32/19403218.html (accessed on 5 February 2020).

Cnaan, Ram A., Richard J. Gelles, and Jill W. Sinha. 2004. Youth and Religion: The Gameboy Generation Goes to “Church". Social Indicators Research 68: 175-200. [CrossRef]

Court, Deborah. 2016. How shall we study religious school culture? Religious Education 101: 233-41. [CrossRef]

Dávila, Juan Francisco, Mónica Casabayó, and W. Rayborn Steven. 2018. Religious or secular? School type matters as a moderator between media exposure and children's materialism. International Journal of Consumer Studies 42: 779-91. [CrossRef]

Davis, Shannon N., and Theodore N. Greenstein. 2009. Gender Ideology: Components, Predictors, and Consequences. Annual Review of Sociology 35: 87-105. [CrossRef]

Díaz, Carlos. 2002. Las preocupaciones del profesor de religión. Revista Española de Pedagogía LX: 301-18.

Díaz, Rafael, Salvador Giner, and Fernando Velasco. 2006. Formas Modernas de Religión. Madrid: Alianza.

Dinham, Adam, and Martha Shaw. 2017. Religious Literacy through Religious Education: The Future of Teaching and Learning about Religion and Belief. Religions 8: 119. [CrossRef]

Elzo, Javier. 2006. Los Jóvenes y la Felicidad. Madrid: PPC.

Esteban, Francisco. 2018. Ética del Profesorado. Barcelona: Herder. 
Fowler, James W., and Mary Lynn Dell. 2004. Stages of faith and identity: Birth to teens. Child and Adolescent Psychiatric Clinics of North America 13: 17-33. [CrossRef]

Fullat, Octavi. 2006. Antropología de lo religioso. Bordón 58: 467-75.

Funes, María Jesús. 2008. Informe Juventud en España. Tomo 4. Cultura, Política y Sociedad. Madrid: Instituto de la Juventud.

García, Raiza, Mirian Grimaldo, and Eduardo Luis Manzanares. 2016. Jerarquía de valores entre estudiantes de secundaria de colegio religioso y colegio laico de Lima. Liberabit 22: 229-38.

Gervilla, Enrique. 2000a. Un modelo axiológico de educación integral. Revista Española de Pedagogía 215: 39-58.

Gervilla, Enrique. 2000b. Valores de la Educación Integral. Bordón 52: 523-35.

Gervilla, Enrique. 2002. Educadores del futuro, valores de hoy. Revista de Educación de la Universidad de Granada 15: 7-25.

Gervilla, Enrique. 2006. La enseñanza religiosa en los centros educativos. Bordón 58: 457-62.

Gervilla, Enrique, Pilar Casares, Socoro Entrena, Gracia González, Francisco Javier Jiménez, Teresa Lara, Marcos Santos, and Andrés Soriano. 2018. Test de Valores Adaptado (TVA_adaptado). Registro de la Propiedad Intelectual No. 04/2017/1538. April 11.

Giraudo, Aldo. 2012. Estudio Introductorio y Notas Históricas de Memorias del Oratorio. Madrid: CCS.

Gobernado, Rafael. 2003. Consecuencias ideacionales del tipo de escuela (pública, privada religiosa y privada laica). Revista Española de Pedagogía LXI: 439-57.

González-Anleo, Juan María. 2006. Sentidos y creencias religiosas de los jóvenes españoles. Bordón 58: 477-91.

González-Anleo, Juan María. 2017a. Valores morales, finales y confianza en las instituciones: Un desgaste que se acelera. In Jóvenes Españoles Entre dos Siglos 1984-2017. Edited by Juan María González-Anleo and José A. López-Ruiz. Madrid: Fundación SM, pp. 13-52.

González-Anleo, Juan María. 2017b. Jóvenes y religión. In Jóvenes Españoles Entre dos Siglos 1984-2017. Edited by Juan María González-Anleo and José A. López-Ruiz. Madrid: Fundación SM, pp. 235-80.

González-Blasco, Pedro. 2006. La socialización religiosa de los jóvenes españoles: Familia y escuela. Bordón 58: 493-518.

González-Gijón, Gracia, Enrique Gervilla, and Nazaret Martínez-Heredia. 2019. El valor religioso hoy y su incidencia en la enseñanza religiosa escolar. Publicaciones 49: 215-28. [CrossRef]

Graciliano, Jesús. 2013. Don Bosco y los emigrantes. Educación y Futuro 28: 151-81.

Guttmann, Joseph. 1984. Cognitive Morality and Cheating Behavior in Religious and Secular School Children. The Journal of Educational Research 77: 249-54. [CrossRef]

Habermas, Jürgen. 2006. Religion in the Public Sphere. European Journal of Philosophy 14: 1-25. [CrossRef]

Hofman, Amos. 2007. The politics of national education: Values and aims of Israeli history curricula, 1956-1995. Journal of Curriculum Studies 39: 441-70. [CrossRef]

Hofmann, Nadi. 2007. Do students' values change in different types of schools? Journal of Moral Education 36: 453-73. [CrossRef]

Holm, Kriistina, Petri Nokelainen, and Kirsi Tirri. 2014. Finnish secondary school students' interreligious sensitivity. British Journal of Religious Education 36: 315-31. [CrossRef]

Ibáñez, José Antonio. 2002. Las Naciones Unidas y el ámbito de la libertad religiosa: Una segunda mirada. Revista Española de Pedagogía LX: 209-24.

Ibáñez, José Antonio. 2006. Libertad religiosa y enseñanza religiosa escolar en una sociedad abierta. Bordón 58: 599-614.

Izcue, Maravillas. 2013. Conocer a Don Bosco hoy. Educación y Futuro 28: 9-10.

Jokić, Boris. 2015. An easy A or a question of belief: Pupil attitudes to Catholic religious education in Croatia. British Journal of Religious Education 37: 4-19. [CrossRef]

Kulska, Joanna. 2020. Religious Engagement and the Migration Issue: Towards Reconciling Political and Moral Duty. Religions 11: 236. [CrossRef]

Lifshitz, Hefziba, and Rivka Glaubman. 2002. Religious and secular students' sense of self-efficacy and attitudes towards inclusion of pupils with intellectual disability and other types of needs. Journal of Intellectual Disability Research 46: 405-18. [CrossRef]

Lipovetsky, Gilles. 2016. La Era del Vacío. Barcelona: Anagrama.

López, Paco. 2015. Las intuiciones pedagógicas de Juan Bosco. Una lectura desde la educación social. Educació Social. Revista d'Intervenció Socioeducativa 6: 102-19. 
López-Ruiz, José A. 2017. La centralidad de la familia para los jóvenes: Convivencia, libertad y educación. In Jóvenes Españoles Entre dos Siglos 1984-2017. Edited by Juan María González-Anleo and José A. López-Ruiz. Madrid: Fundación SM, pp. 105-64.

Mather, Darin M. 2018. Gender Attitudes in Religious Schools: A Comparative Study of Religious and Secular Private Schools in Guatemala. Religions 9: 219. [CrossRef]

Muñoz-García, Antonia, and María Dolores Villena-Martínez. 2018. Used Sources of Spiritual Growth for Spanish University Students. Religions 9: 186. [CrossRef]

Nanni, Carlo. 2013. Los puntos clave del sistema preventivo. Educación y Futuro 28: 11-14.

Núñez, José Miguel. 2013. Don Bosco en el ocaso de la modernidad: Aproximación histórica-crítica al contexto que forjó al educador-pastor. Educación y Futuro 28: 17-38.

Organización de las Naciones Unidas. 1948. Declaración Universal de los Derechos Humanos. Available online: https://www.un.org/es/universal-declaration-human-rights/ (accessed on 15 January 2020).

Organización Mundial de la Salud. 2018. Desarrollo en la Adolescencia. Available online: http://www.who.int/ maternal_child_adolescent/topics/adolescence/dev/es/ (accessed on 22 April 2020).

Puelles, Manuel. 2006. Religión y escuela pública en nuestra historia: Antecedentes y procesos. Bordón 58: 521-35.

Raban, Nicoleta, and Ileana Loredana. 2015. Religiosity and proactive coping with social difficulties in Romanian adolescents. Journal of Religion \& Health 54: 1647-59. [CrossRef]

Real Academia Española. 2019. Diccionario de la Lengua Española. Available online: https://dle.rae.es/ (accessed on 5 May 2020).

Rodríguez, Manuel, and Juan Jesús Iglesias. 2018. Don Bosco: Una propuesta educativa adecuada a los presos jóvenes. Salesianum 80: 109-32.

Rojano, Jesús. 2009. ¿Son religiosos o no los jóvenes de hoy? Crítica 962: 42-47.

Rojano, Jesús. 2013. La teología y moral que aprendió el joven Juan Bosco y la influencia en su obra. Educación y Futuro 28: 61-81.

Romero, Javier. 2010. Jóvenes y religión en un mundo de cambio. El caso de los jóvenes chilenos. Ciencias Sociales y Religión 12: 147-56. [CrossRef]

Rymarz, Richard, and Anthony Cleary. 2018. Examining some aspects of the worldview of students in Australian Catholic schools: Some implications for religious education. British Journal of Religious Education 40: 327-36. [CrossRef]

Salazar, Francisco. 2013. El antiguo alumno en la pedagogía de don Bosco. Educación y Futuro 28: 223-25.

Sander, William, and Danny Cohen-Zada. 2012. Religiosity and parochial school choice: Cause or effect? Educations Economics 20: 474-83. [CrossRef]

Schewel, Benjamin. 2018. Post-Secularism in a World-Historical Light: The Axial Age Thesis as an Alternative to Secularization. Religions 9: 139. [CrossRef]

Ter Avest, Ina, Dan-Paul Jozsa, and Thorsten Knauth. 2010. Gendered subjective theologies: Dutch teenage girls and boys on the role of religion in their life. Religious Education 105: 374-94. [CrossRef]

Tuastad, Svein. 2016. What Is It Like to Be a Student in a Religious School? Religion E Education 43: 60-76. [CrossRef]

Uecker, Jeremy E. 2008. Alternative schooling strategies and the religious lives of American adolescents. Journal for the Scientific Study of Religion 47: 563-84. [CrossRef] [PubMed]

Uecker, Jeremy E. 2009. Catholic schooling, protestant schooling, and religious commitment in young adulthood. Journal for the Scientific Study of Religion 48: 353-67. [CrossRef]

Valls, Maite. 2010. Las creencias religiosas de los jóvenes. In Jóvenes españoles 2010. Edited by Juan González and Pedro González. Madrid: Fundación SM, pp. 175-228.

Vizcaíno, Eduardo. 2015. Espiritualidad líquida. Secularización y transformación de la religiosidad juvenil. OBETS. Revista de Ciencias Sociales 10: 437-70. [CrossRef]

Zarzycka, Beata, Anna Tychmanowicz, and Dariusz Krok. 2020. Religious Struggle and Psychological Well-Being: The Mediating Role of Religious Support and Meaning Making. Religions 11: 149. [CrossRef]

(C) 2020 by the authors. Licensee MDPI, Basel, Switzerland. This article is an open access article distributed under the terms and conditions of the Creative Commons Attribution (CC BY) license (http://creativecommons.org/licenses/by/4.0/). 